\title{
Obedience and Income Levels
}

\author{
Kaitlyn Harger \\ Department of Economics \\ West Virginia University \\ Morgantown, WV 26506-6025 \\ Kaitlyn.Wolf@mail.wvu.edu \\ Joshua C. Hall \\ Department of Economics \\ West Virginia University \\ 1601 University Ave. \\ PO Box 6025 \\ Morgantown, WV 26506-6025 \\ joshua.c.hall@gmail.com
}

\begin{abstract}
We revisit the relationship between informal institutions and income levels. The empirical literature on institutions finds that indices of "informal institutions" such as trust, respect, respect, self-determination, and obedience are more important than "formal institutions" such as constitutional constraints in explaining income levels across countries. We add to this literature in two ways. First, we separate out the index of informal institutions into its component parts to see which informal institutions are primary. Second, we construct two new measures of obedience to test the robustness of obedience. Our reduced-form results indicate the primacy of obedience over other informal institutions.
\end{abstract}

JEL classifications: O13, O17

Key Words: informal institutions, formal institutions, culture, economic development 


\section{Informal Institutions and Income Levels}

\section{Introduction}

In the last two decades a large literature has developed that focuses on the role institutions play in fostering economic development. This scholarship finds that institutions are responsible for the divergence in prosperity across countries (Dawson 1998; Acemoglu 2002; Glaeser et al. 2004). Uncertainty still exists, however, regarding the relative importance of different types of institutions and their relationships with growth. More recent research examines the relative effects of informal versus formal institutions on prosperity to try to establish whether informal institutions such as trust, respect, self-determination, and obedience are more important for economic development than formal institutions like constitutional constraints. (Tabellini 2010; Williamson 2010).

The origins of the cross-country empirical literature on informal institutions goes back to the work of Knack and Keefer's (1997) important work on trust and economic performance using data from the World Values Survey (2009). In an influential paper, Tabellini (2010) builds on Knack and Keefer's work by introducing three new aspects of informal institutions: respect, self-determination, and obedience. Like Knack and Keefer, Tabellini finds that elements of social capital such as self-determination, trust, and respect are favorable to economic development but that obedience is negatively related. In addition, he presents some preliminary evidence that informal institutions might be at least as important as formal institutions as a determinant of economic performance. In an extension of Tabellini’s work, Williamson (2010) combines the informal measures of institutions used by Tabellini into an index of informal 
institutions. She does the same thing with the formal measures of institutions used by Glaeser et al (2004). Looking at per capita GDP levels in 2000, she finds formal institutions to be negatively related to development differences across countries and informal institutions to be positively related. For more on the reasons why informal institutions might be more important than formal ones, we refer the reader to Williamson (2008).

In this paper we build off of Williamson's (2010) important work by disaggregating her formal and informal indices in order to better facilitate the examination of each individual measure of informal institutions and their relation to GDP per capita. In particular, we are interested in more closely analyzing the relationship between obedience and income levels. We do in two ways. First, we eschew principal component analysis (PCA) and simple pairwise correlations that tell us little about the effect of obedience holding other measures of institutions constant. Second, we attempt to clarify the relationship between obedience and development by analyzing two additional measures of obedience from the World Values Survey. Due to the difficulty in measuring institutions while separating out endogenous influences, this paper does not attempt to address the issue of causality. Rather, this short paper is an attempt to unbundle informal institutions - in particular obedience - in order to better understand the role of obedience in economic development and to spur additional data collection and research.

The paper progresses as follows. Section 2 describes our data, while Section 3 discusses our empirical approach and results. Section 4 concludes.

\section{Data and Empirical Approach}

Our primary interest in this paper is further examining the role that informal institutions play in in per capita GDP levels. For that reason we begin with the basic data of Tabellini (2010) and 
Williamson (2010). Both papers use questions from the 1990, 1995, and 2000 waves of the World Values Survey (2009) to measure informal institutions like trust, respect, selfdetermination, and obedience. We also have a secondary interest is in seeing how robust obedience is to alternative definitions of the concept so we construct two additional measures of obedience from the World Values Survey.

In the literature, obedience is typically thought to be negatively related to growth because obedience to cultural norms can be unconditional and stifling of individual initiative and group cooperation (Tabellini 2010). While it is true that an individual abiding by social rules constrains their opportunities, the impact of obedience on growth and development reflects the level of other institutions within society. In societies with high levels of obedience to authority or other norms, citizens are aware of how other members will usually act in market transactions. When dealing in infrequent transactions that are not repeated, exchange with an obedient partner will increase predictability, reduce transaction costs, and thereby promote efficiency. From this perspective, higher levels of obedience promote market exchange and thus might promote higher levels of GDP.

Our first measure of obedience we call "Obedience - Child Quality.” This is the measure of obedience used by Tabellini (2010) and Williamson (2010). Obtained from a World Values Survey question asking respondents to choose from a list important child qualities, respondents who mention obedience as an important child quality are given a score of 1 . While Tabellini (2010) finds this to be negatively related to average output from 1995 to 2000, we have concerns that this might not be measuring the level of obedience in society overall but rather be reflective of other features of parenting, such as permissive parenting styles. 
Our second measure gets more directly at the double-edged nature of obedience. “Obedience - Instructions” comes from the World Values Survey (2009) question that asks respondents, "People have different ideas about following instructions at work. Some say that one should follow one's superior's instructions even when one does not fully agree with them. Others say that one should follow one's superior's instructions only when one is convinced that they are right. With which of these two opinions do you agree?” Respondents are given a score of one if they indicate willingness to follow instructions without any questions and a score of zero if the individual must be convinced first. An appealing feature of this measure of obedience is that by asking about job duties, it is most separate from other contemporary formal and informal institutions.

Our third measure of obedience - "Obedience - Authority Respect” - asks respondents about their feelings towards greater respect for authority in the future. Respondents indicating they feel this is a "good thing" are given a score of one whereas respondents indicating this is a "bad thing" are given a score of zero. This question may be flawed because it may be related to current sentiment towards government within that country. If that is the case obedience would be contaminated by the current social environment.

In addition to these measures of formal institutions, our analysis looks to important institutional papers such as La Porta et al. (1999), La Porta et al. (2004), Glaeser et al. (2004), and Williamson (2010) for measures of formal constitutional constraints and control variables. Description of all the variables employed in our analysis is presented in Table 1. 


\section{Empirical Approach and Results}

To be as directly comparable to the previous literature such as Tabellini (2010) and Williamson (2010), we use the log of Gross Domestic Product (GDP) per capita in 2000 as our dependent variable and estimate our results using OLS with robust standard errors. Where our work most directly differs from Tabellini (2010) and Williamson (2010) is that we avoid PCA and control for other formal and informal measures of institutions in all regressions. While reducing our degrees of freedom, our approach has two advantages. First, our results are more directly interpretable as they are not the result of an underlying PCA. Second, our approach clarifies the separate role of each informal institution in the development process.

Our regression results on a cross-section of countries are presented below in Table 2. To correct for heteroskedasticity, robust standard errors are used in all regressions. Variance inflation factors for all regressions specified in Table 2 fall below the multicollinearity benchmark set forth in Kennedy (2003). Due to the limited number of countries involved in various waves of the World Values Survey (2009) and data limitations on some of our formal measures, our sample is limited to 36 countries in Column 1 and 37 countries in Columns 2 and 3.

The first important thing to note in our results is that all three measures of obedience are positively related to per capita GDP levels in 2000 in a statistically significant manner. Most surprising is the result using the measure of obedience we call "Obedience - Child Quality.” Recall that this is based on the same question as used by Tabellini (2010), who found the opposite results in much more simpler regressions with few or no controls. Whether our opposite findings are due to a smaller sample size or the fact that we control for formal and informal institutions is unclear. However, the fact that we find similar positive results while employing 
different measures of obedience in the regressions presented in columns 1 and 3 makes us more confident in our results. It is important to note that our results in this area are not directly comparable to the results of Williamson (2010) since she only employed a PCA measure of informal institutions, not the separate measures.

Another important result to highlight is the primacy of obedience over other informal measures. These results show that when controlling for factors such as urban population, latitude, English legal origin, etc., and a variety of formal institutions, obedience maintains relative primacy over other measures of informal institutions. Trust is the only informal institutional measure to be statistically significant in any regression and in that case only one of the three. These findings provide some evidence of the relative importance that obedience might play in enhancing market efficiency. At a minimum, however, these findings suggest that most measures of formal and informal institutions might not be as important as once thought in determining current income levels. Certainly, further research is warranted.

\section{Conclusion}

Our results show that when disaggregated the effect of informal institutions on economic performance might be different than what has been previously presented in the literature. Our results, which incorporate new measures of obedience and explicitly include other important formal and informal institutions simultaneously, suggest that obedience has relative primacy over other measures of informal institutions such as trust, respect, and self-determination.

Our results provide some suggestive evidence that efficiency implications attributed to trust, respect, and self-determination are not to be found when other formal and informal institutions are taken into account. This finding, however, may be a feature of the limited data available and by no means is conclusive evidence that trust, respect, and self-determination do 
not have a significant relationship with GDP per capita. Due to the evidence presented within this paper, future research should look into the different relationships present between varied measures of obedience, other formal and informal institutions, and GDP per capita. 


\section{References}

Acemoglu, D., Johnson, S., and J. Robinson. 2002. "Reversal of Fortune: Geography and Institutions in the Making of the Modern World Income Distribution”. The Quarterly Journal of Economics, 117(4): 1231-1294.

Barro, Robert J. and Jong-wha Lee. 2000. “International Data on Educational Attainment: Updates and Implications”. Oxford Economic Papers. 53(3): 2001.

Dawson, John. 1998. "Institutions, Investment, and Growth: New Cross-Country and Panel Data Evidence.” Economic Inquiry 36:4 (1998), 603-19.

Glaeser, E. L., La Porta, R., Lopeez-De-Silanes, F. and A. Shleifer. 2004. "Do Institutions Cause Growth?”. Journal of Economic Growth, 9: 271-303.

Kennedy, P. 2003. A Guide to Econometrics, 5th edition. Cambridge: MIT Press.

Knack, S. and P. Keefer. 1997. "Does Social Capital have an Economic Payoff?”. The Quarterly Journal of Economics, 112(4): 1251-1288.

La Porta, R., Lopez-de-Silanes, F.,Shleifer, A., and R. Vishny. 1999. "The Quality of Government.” Journal of Law, Economics, and Organization, 15(1): 222-279.

La Porta, R., Lopez-de-Silanes, F., Pop-Eleches, C. and A. Shleifer. 2004. "Judicial Checks and Balances”. Journal of Political Economy, 112(2): 445-470.

Tabellini, G. 2010. "Culture and Institutions: Economic Development in the Regions of Europe". Journal of the European Economic Association, 8(4): 677-716.

Williamson, C. R. 2010. "Informal Institutions Rule: Institutional Arrangements and Economic Performance”. Public Choice, 139(3): 371-387.

World Values Survey. 2009. “Integrated Values Surveys 1981-2008 [electronic file].” Madrid: World Values Survey Association. 


\section{Table 1}

\section{Variable Descriptions and Descriptive Statistics}

\begin{tabular}{|c|c|}
\hline Variable & Description \\
\hline Trust Of Others in Society & If individual indicates most people can be trusted 1,0 otherwise.* \\
\hline Respect As Important Child Quality & $\begin{array}{l}\text { If individual mentions respect as an important child quality then } 1 \text {, } \\
0 \text { otherwise. }\end{array}$ \\
\hline Determination Over Own Life & $\begin{array}{l}\text { Score between } 1 \text { and } 10 \text { indicating individual's freedom of choice } \\
\text { and control in their own life.* }\end{array}$ \\
\hline Obedience - Instructions & $\begin{array}{l}\text { If individual indicates willingness to follow instructions without } \\
\text { any questions then 1, } 0 \text { otherwise.* }\end{array}$ \\
\hline Obedience - Child Quality & $\begin{array}{l}\text { If individual mentions obedience as an important child quality } \\
\text { then } 1,0 \text { otherwise.* }\end{array}$ \\
\hline Obedience - Authority Respect & $\begin{array}{l}\text { If individual indicates greater respect for authority within country } \\
\text { is a good thing then } 1,0 \text { otherwise.* }\end{array}$ \\
\hline Judicial Independence & $\begin{array}{l}\text { The normalized sum of measures of tenure of supreme court } \\
\text { justices, tenure of highest ranked judges ruling on administrative } \\
\text { issues, and existence of case law. }\end{array}$ \\
\hline Judicial Review & $\begin{array}{l}\text { The sum of two variables measuring judicial review and } \\
\text { constitutional stability. }\end{array}$ \\
\hline Plurality & $\begin{array}{l}\text { If country uses a winner-take-all system for legislators then } 1,0 \\
\text { otherwise. }\end{array}$ \\
\hline Proportional Representation & $\begin{array}{l}\text { If candidates are elected based on the \% of votes received by } \\
\text { their party then } 1,0 \text { otherwise. }\end{array}$ \\
\hline Urban Population & Urban population in 1960 \\
\hline Ethnolinguistic Fractionalization & $\begin{array}{l}\text { Average value of five different indicies of ethnolinguistic } \\
\text { fractionalization. }\end{array}$ \\
\hline Government Consumption & $\begin{array}{l}\text { General government final consumption expenditure as a \% of } \\
\text { GDP in } 2000 .\end{array}$ \\
\hline English Legal Origin & $\begin{array}{l}\text { If the legal origin of the company law or commercial code is } \\
\text { English then } 1,0 \text { otherwise }\end{array}$ \\
\hline Corruption & $\begin{array}{l}\text { Perceptions of the degree of corruption as seen by individuals in } \\
\text { country. Ranges from } 10 \text { (highly clean) and zero (highly corrupt). }\end{array}$ \\
\hline Latitude & $\begin{array}{l}\text { The absolute value of the latitude of the country, scaled to take } \\
\text { values between } 0 \text { and } 1 .\end{array}$ \\
\hline Educational Attainment & Years of schooling of the total population aged over 25 in 1960. \\
\hline
\end{tabular}

\footnotetext{
* Indicates individual response aggregated to national measure.
} 
Table 2

Country Level Regressions of Institutions on Log GDP Per Capita in 2000

\begin{tabular}{|c|c|c|c|}
\hline & (1) & $(2)$ & (3) \\
\hline Trust Of Others in Society & $\begin{array}{r}0.009 \\
(0.088)\end{array}$ & $\begin{array}{r}0.121 \\
(0.105)\end{array}$ & $\begin{array}{l}0.261 \text { *** } \\
(0.135)\end{array}$ \\
\hline Respect As Important Child Quality & $\begin{array}{r}0.181 \\
(0.171)\end{array}$ & $\begin{array}{r}0.090 \\
(0.136)\end{array}$ & $\begin{array}{r}-0.015 \\
(0.134)\end{array}$ \\
\hline Determination Over Own Life & $\begin{array}{r}0.066 \\
(0.140)\end{array}$ & $\begin{array}{r}0.086 \\
(0.179)\end{array}$ & $\begin{array}{r}-0.081 \\
(0.112)\end{array}$ \\
\hline Obedience - Instructions & $\begin{array}{l}0.342 \text { ** } \\
(0.127)\end{array}$ & & \\
\hline Obedience - Child Quality & & $\begin{array}{l}0.314^{* *} \\
(0.113)\end{array}$ & \\
\hline Obedience - Authority Respect & & - & $\begin{array}{l}0.287 \text { *** } \\
(0.068)\end{array}$ \\
\hline Judicial Independence & $\begin{array}{r}-0.385 \\
(0.577)\end{array}$ & $\begin{array}{r}-0.249 \\
(0.538)\end{array}$ & $\begin{array}{r}-0.489 \\
(0.413)\end{array}$ \\
\hline Judicial Review & $\begin{array}{r}-0.707 \\
(0.435)\end{array}$ & $\begin{array}{r}-0.335 \\
(0.396)\end{array}$ & $\begin{array}{c}-0.136 \\
(0.382)\end{array}$ \\
\hline Plurality & $\begin{array}{r}0.407 \\
(0.262)\end{array}$ & $\begin{array}{r}0.297 \\
(0.238)\end{array}$ & $\begin{array}{l}0.441 \text { ** } \\
(0.161)\end{array}$ \\
\hline Proportional Representation & $\begin{array}{c}0.799 * * \\
(0.318)\end{array}$ & $\begin{array}{r}0.528 \\
(0.332)\end{array}$ & $\begin{array}{l}0.624 \text { *** } \\
(0.218)\end{array}$ \\
\hline Urban Population & $\begin{array}{l}-0.024 * * \\
(0.009)\end{array}$ & $\begin{array}{l}-0.031 * * \\
(0.011)\end{array}$ & $\begin{array}{l}-0.028 * * * \\
(0.008)\end{array}$ \\
\hline Ethnolinguistic Fractionalization & $\begin{array}{l}-1.375 * * * \\
(0.467)\end{array}$ & $\begin{array}{l}-1.928 * * \\
(0.753)\end{array}$ & $\begin{array}{l}-0.911 * \\
(0.456)\end{array}$ \\
\hline Government Consumption & $\begin{array}{c}0.046 * \\
(0.026)\end{array}$ & $\begin{array}{r}0.031 \\
(0.023)\end{array}$ & $\begin{array}{r}0.003 \\
(0.019)\end{array}$ \\
\hline English Legal Origin & $\begin{array}{r}-0.432 \\
(0.275)\end{array}$ & $\begin{array}{r}-0.324 \\
(0.324)\end{array}$ & $\begin{array}{l}-0.680 * * \\
(0.306)\end{array}$ \\
\hline Corruption & $\begin{array}{c}0.197 * \\
(0.106)\end{array}$ & $\begin{array}{c}0.218 * \\
(0.123)\end{array}$ & $\begin{array}{r}0.114 \\
(0.074)\end{array}$ \\
\hline Latitude & $\begin{array}{l}1.687 \text { ** } \\
(0.746)\end{array}$ & $\begin{array}{l}2.028 * * \\
(0.866)\end{array}$ & $\begin{array}{l}2.544 \text { *** } \\
(0.635)\end{array}$ \\
\hline Educational Attainment & $\begin{array}{l}1.257 \text { *** } \\
(0.279)\end{array}$ & $\begin{array}{l}1.979 * * * \\
(0.523)\end{array}$ & $\begin{array}{l}1.559 \text { *** } \\
(0.282)\end{array}$ \\
\hline Constant & $\begin{array}{l}4.224 * \\
(2.403)\end{array}$ & $\begin{array}{r}4.006 \\
(2.612)\end{array}$ & $\begin{array}{l}5.769 \text { *** } \\
(1.670)\end{array}$ \\
\hline \# Observations & 36 & 37 & 37 \\
\hline R-squared & 0.90 & 0.89 & 0.93 \\
\hline
\end{tabular}

Note: Robust standard errors in parentheses. Significance level: ${ }^{* * *}$ at $1 \%$, ** at $5 \%$, * at $10 \%$. 